\title{
Adoption of technology and innovation among rural women for better life-style management
}

\section{B. Jyotsna Devi}

Author for Correcpondence :

\section{B. Jyotsna Devi}

Department of Home Science,

Sri Venkateswara University,

Tirupati (A.P.) India

Email : jyotsnadevi95@gmail.

com
Received: 03.09.2020; Revised: 15.10.2020; Accepted: 29.10 .2020

ABSTRACT : In rural society, though technology use is one aspect of social justice, bringing hope to the hopeless can be facilitated by use of technology to improve their quality of life. Technology could enhance their capabilities and encourage their participation in the process of development. But the promotion of technology can not be accelerated unless a climate of receptivity and an awareness of the importance of technology in modern life are created in the general public. Use of local resources and skills for the design and development of technologies would be helpful towards their speedy acceptance and adoption. The present study was undertaken in Chandragiri and Ramachandrapuram Mandals of Chittoor district of Andhra Pradesh. The total sampling technique was adopted in the selection of respondents. A structured interview schedule prepared based on the objectives of the study, was used for collecting primary data. The major findings of the study showed that one third of the respondents were in the age group of 30-39 years. 84 per cent of the respondents were married. 41 per cent of the respondents were illiterates. Majority of the respondents belonged to the nuclear family system. 38 per cent of the respondents belonged to the income group of Rs. 2001-3000 per month. 85 per cent of the respondents were using modern kitchen ware technologies which enable them to cook quickly and comfortably. This enabled them to have more time to focus on their income earning activities. 76 per cent of the respondents reported that modern communication and information Technologies have helped them in the adoption of modern agricultural equipment, commercial crops, seeds and pesticides and market prices etc. majority of the respondents reported that adoption of new technologies has helped them to increase their incomes.

KEY WORDS: Modern technology, Rural women, Quality of life

- HOW TO CITE THIS PAPER : Devi, B. Jyotsna (2020). Adoption of technology and innovation among rural women for better life-style management. Asian J. Home Sci., 15 (2) : 227-234, DOI: 10.15740/HAS/ AJHS/15.2/227-234. Copyright@ 2020: Hind Agri-Horticultural Society. 